\section{Bird Community Structure of Suranaree University of Technology Campus, Nakhon Ratchasima Province, Thailand}

\author{
Archana Naithani, Pongthep Suwanwaree* and Bartosz Nadolski \\ School of Biology, Institute of Sciences, Suranaree University of Technology, \\ Nakhon Ratchasima, Thailand
}
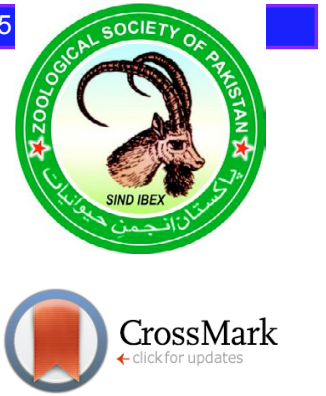

\begin{tabular}{l} 
Article Information \\
Received 25 October 2017 \\
Revised 25 December 2017 \\
Accepted 10 January 2018 \\
Available online 17 May 2018 \\
Authors' Contribution \\
\hline AN designed the study, collected \\
data, analysis the results and wrote \\
the manuscript. PS reviewed the \\
manuscript and interpreted results. \\
BN helped in planning and conducting \\
the study. \\
Key words \\
Avian diversity, Bird community, \\
Ecosystem, Threatened species.
\end{tabular}

\begin{abstract}
A B S T RA C T
Weekly surveys following point count method during November 2016 to April 2017 in the campus of Suranaree University of Technology, Nakhon Ratchasima province, resulted in the identification of 94 bird species belonging to 12 orders and 35 families. Altogether 3,328 individuals were observed. Out of 35 Families, Sturnidae and Sylviidae had the highest number of species ( 5 species each). Six simple dietary guilds were observed during the present study; the maximum number of species belonged to insectivore group and minimum to nectarivore. Analysis of data revealed that the average of species diversity index of the avian community (H') during the study period was 3.88. Using the Berger-Parker dominance value, we found the most abundant species was House sparrow (Passer domesticus), followed by Oriental turtle dove (Streptopelia orientalis), Peaceful Dove (Geopelia striata), Common Myna (Acridotheres tristis) and Red collared dove (Streptopelia tranquebarica). The threatened status of birds given in the checklist is as per IUCN Red List of Threatened Species 2017. The presence of Alexandrine parakeet (Psittacula eupatria) in the study, listed under the category 'Near Threatened' in the IUCN Red List, is a matter of concern. The findings of the present study would provide the baseline information about the composition of the avian community and its distribution in the Suranaree University of Technology, which is an important ecosystem for the conservation of avian biodiversity. Many other areas adjacent to the campus also require attention for the inventory of avian communities. Therefore, a long-term database on exhaustive and intensive study of the North East Thailand is required.
\end{abstract}

\section{INTRODUCTION}

A vifauna is considered as one of the important indicators of a country's environmental health (Collar and Andrew, 1988) as its high and low diversities are directly related to environmental condition of the area (Loreau et al., 2001). Bird communities are frequently studied for conservation assessment and monitoring (Best and Kessler, 1995), being responsive to habitat changes like fragmentation and shifts in habitat quality or extent (Greenberg, 1996). Urbanization and industrialization both are source of disturbance in bird communities causing habitat degradation and fragmentation, which results in a decrease in overall biodiversity (Bolger, 2002; DeStefano and DeGraaf, 2003; Kristan et al., 2003). Urban expansion results in the conversion of croplands, grasslands, and forested areas into built-up environments on a large scale (Alig and Healy, 1987). Different habitats provide good abode for wildlife species in an area. Suranaree University of Technology (SUT) campus is located in between

\footnotetext{
* Corresponding author: pongthep@sut.ac.th 0030-9923/2018/0004-1257 \$ 9.00/0

Copyright 2018 Zoological Society of Pakistan
}

$14.872917^{\circ} \mathrm{N}$ and $102.0237^{\circ} \mathrm{E}$, in the outskirts of Nakhon Ratchasima city, having green areas (natural and planted forests and water reservoir), accounting for $95 \%$ of the total area. The university aims to restore deforested area by planting new trees without destroying any former trees/ plantations. In outer parts of the campus, people have their own agricultural land where crops, like cassava, maize and sugarcane are cultivated. Many studies have been conducted on the associations of particular bird species, with habitats along environmental gradients in Asian subcontinent (e.g., Bond, 1957; James, 1971; Cody, 1974; Able and Noon, 1976; Smith, 1977) and in habitats with either similar or contrasting physical characteristics in West Virginia (Maurer and Whitmore, 1981). Some studies have been conducted on bird communities of disturbed lowland forests (Round and Brockelman, 1998), bird assemblages around western forest complex of Thailand (Chaiyes et al., 2009), in old settlements area (Duengkae et al., 2001; Duengkae, 2010), bird species diversity and abundance in hill evergreen forests (Siri et al., 2013). Avifaunal diversity in different parts of Thailand i.e., Bangkok (Khobkhet, 2002), Kasetsart University Campus (Duengkae, 2010), Maejo University Campus (Tarachai, 2012) Chamchuri Park Bangkok (Duengkae, 2010; Meckvichai, 2013) have 
also been studied. Teampanpong et al. (2003) conducted some comparative studies based on habitat structure. Prathumthong and Patthanavibool (2006) studied the bird community structure along altitudinal gradient, while in some studies their role as environmental indicators has been defined (Gregory et al., 2003; Wongthirawat, 2009). Some studies have been done on the species diversity and their abundance (Khan and Khancharat, 2012; Khachonpisitsak and Eiamprasert, 2015) which are restricted to certain parts of Thailand. Studies on diversity, distribution, relative abundance and status of birds conducted in different parts of Thailand has been reported by different workers through different studies such as, changes in bird diversity associated with urbanization have been reported by Reynaud and Thioulouse (2000), Mortberg (2001), Crooks et al. (2004) and Lim and Sodhi (2004); from Bangkok (Khobkhet, 2002; Round, 2008) and some based on urban reserves (Sukmasuang et al., 2007, 2009). However, the Northeastern Thailand including Nakhon Ratchasima area remained mostly neglected from avian study point of view especially in the context of their status, distribution and habitat association, with the exception of a few studies on reproductive ecology of some pheasants (Iamsiri and Gale, 2008; Round and Gale, 2008; Savini and Sukumal, 2009; Suwanrat et al., 2015). Previous studies on the birds of Suranaree university campus were surveys that focused mostly on taxonomy and distribution, with notes on the general ecology of some other species (Suwanwaree, 2010). Therefore, the present study based on the distribution and status of Avifauna of Suranaree University of Technology was conducted to fill this gap.

\section{MATERIALS AND METHODS}

\section{Study area}

Suranaree University of Technology campus is located at $14.872917^{\circ} \mathrm{N}$ and $102.0237^{\circ} \mathrm{E} ; 251$ above mean sea level. It is spread over 1120 hectares of degraded forest area and has a botanical garden, small parks, playground, some natural patches of forest, plantation, Science Park, Learning Park, University farm, hotel and conference rooms and many other institutional and departmental buildings. The campus is surrounded by some agricultural land and inhabited by a wide variety of plant species, many planted and some naturally growing trees shrubs, and partially disturbed vegetation. The list includes one species of cycad, 308 species of dicots, and 74 species of monocots, making a total of 383 plant species (Thammathaworn et al., 1996). The largest families are Leguminosae (68 species) followed by Gramineae (40 species) (Thammathaworn et al., 1996). In the campus region with academic buildings and residences, some dipterocarp trees such as Shorea siamensis are growing by the B2 teaching building. Some common trees are Azadirachtia indica, Bauhinia saccocalyx, Diospyros rhodocalyx, Acacia leucophloea, Acacia harmandiana, Albizia lebbeck, Albizia lebbekkoides, Albizia procera, Spondia pinnata, Lannea coromandelica and Maerua siamensis besides other evergreen trees, dense shrubs and small trees in between the departments, roadsides, vacant lots and along the periphery of the campus. These often play a key role in providing food (both of floral and faunal origin) and roosting sites for various bird species. The university farm zone and student residential areas were not included in the present study.

\section{Data collection}

Birds were surveyed using 10 minute point counts (Sutherland et al., 2004) in which the surveyor recorded all individuals detected by sight or sound within a $25 \mathrm{~m}$ radius of the point (see Supplementary Table I for sample data form). Twenty five point count stations (PCS) were established at Suranaree University of Technology campus. The radius of each point count station was 25 $\mathrm{m}$, separated by a distance of at least $200 \mathrm{~m}$ to ensure independence among observations. We kept track of date, time and weather conditions. We also recorded all bird species observed even outside of the $25 \mathrm{~m}$ circle in order to develop a detailed species list (Ralph et al., 1996; Bibbly et al., 1998; Cellis-Murillo et al., 2009). All birds seen and heard during 10 minutes, within the fixed radius were recorded, bird songs and calls for the unidentified birds were recorded by using the Zoom H4n handy recorder (Bibbly et al., 1998; Cellis-Murillo et al., 2009, 2012). All birds seen within the respective station and those flying about $10 \mathrm{~m}$ height above the ground over the transect were also recorded. Species less than ten sightings during the study period were considered as the uncommon species. All sampling was done between 6.00 - 11.00 am and 3.30 $6.30 \mathrm{pm}$ during November 2016 to April 2017. Altogether 500 visits $(4 /$ month $\times 5$ months $\times 25$ point count stations $=$ 500) were made during the study period. Patterns of bird census were the same in all the point count stations. The identification of birds in the field was based on Lekagul and Round (2005). The classification and nomenclature of bird species was based on Birdlife International (2014). All observations were recorded in the field. Nocturnal birds and birds flying over or through the survey area were not recorded.

\section{Data analysis}

Bird species diversity (BSD) and bird species 
richness (BSR) were measured using Shannon's index $\left(H^{\prime}\right)$ and Margalef's index, respectively (MacArthur and MacArthur, 1961; Magurran, 2004). Resulting gradient of the Shannon-Weaver diversity index for bird species diversity was also examined by other measures of Richness-Rarefaction and the number of species versus number of individuals. Data were pooled from all point count stations to calculate the relative abundance. Relative abundance of each bird species was also observed using the following formula (RA):

$$
\mathrm{RA}=\text { ni } \times 100 / \mathrm{N}
$$

Where, ni is the number of individuals of $i$ th species and $\mathrm{N}$ is the total number of individuals of all species.

Rank abundance plots were constructed following the methods described by Magurran (1988).

All statistical analysis was performed using software PAST and Biodiversity Pro. And Microsoft Excel for windows.

\section{RESULTS}

A total of 94 bird species belonging to 35 families and 12 orders were recorded from the Suranaree University of Technology campus. Out of 94 bird species 82 species were observed within the 25 point count stations. Twelve (12) species were observed from the same area either moving between point count stations or at other different places in the SUT campus. Family Sturnidae (6 species) and Sylviidae (6 species) comprised of the maximum number of species (Supplementary Table II). The values for Shannon diversity index (H') of bird species, for pooled samples from all the point count stations was $\mathrm{H}^{\prime}=3.8$ (Table I).

The Shannon-Weaver diversity index showed a gradient for bird species diversity in the study area, this gradient was also examined by other measures of RichnessRarefaction and the number of species versus number of individuals. The steepness in the curves showed the higher evenness of bird species in the study area (Fig. 1).

Table I.- Diversity indices of bird community of SUT campus.

\begin{tabular}{lccc}
\hline Diversity indices & $\begin{array}{c}\text { SUT } \\
\text { campus }\end{array}$ & $\begin{array}{c}\text { Lower } \\
\text { limit }\end{array}$ & $\begin{array}{c}\text { Upper } \\
\text { limit }\end{array}$ \\
\hline Taxa_S & 82 & 80 & 82 \\
Individuals & 2625 & 2625 & 2625 \\
Dominance_D & 0.03467 & 0.03265 & 0.03756 \\
Shannon_H & 3.808 & 3.753 & 3.831 \\
Simpson_1-D & 0.9653 & 0.9624 & 0.9674 \\
Evenness_e^H/S & 0.5494 & 0.5227 & 0.5665 \\
Menhinick & 1.6 & 1.561 & 1.6 \\
Margalef & 10.29 & 10.03 & 10.29 \\
Equitability_J & 0.8641 & 0.8526 & 0.8706 \\
Fisher_alpha & 16.07 & 15.59 & 16.07 \\
Berger-Parker & 0.1135 & 0.1006 & 0.1257 \\
\hline
\end{tabular}

\section{Rarefaction Plot}

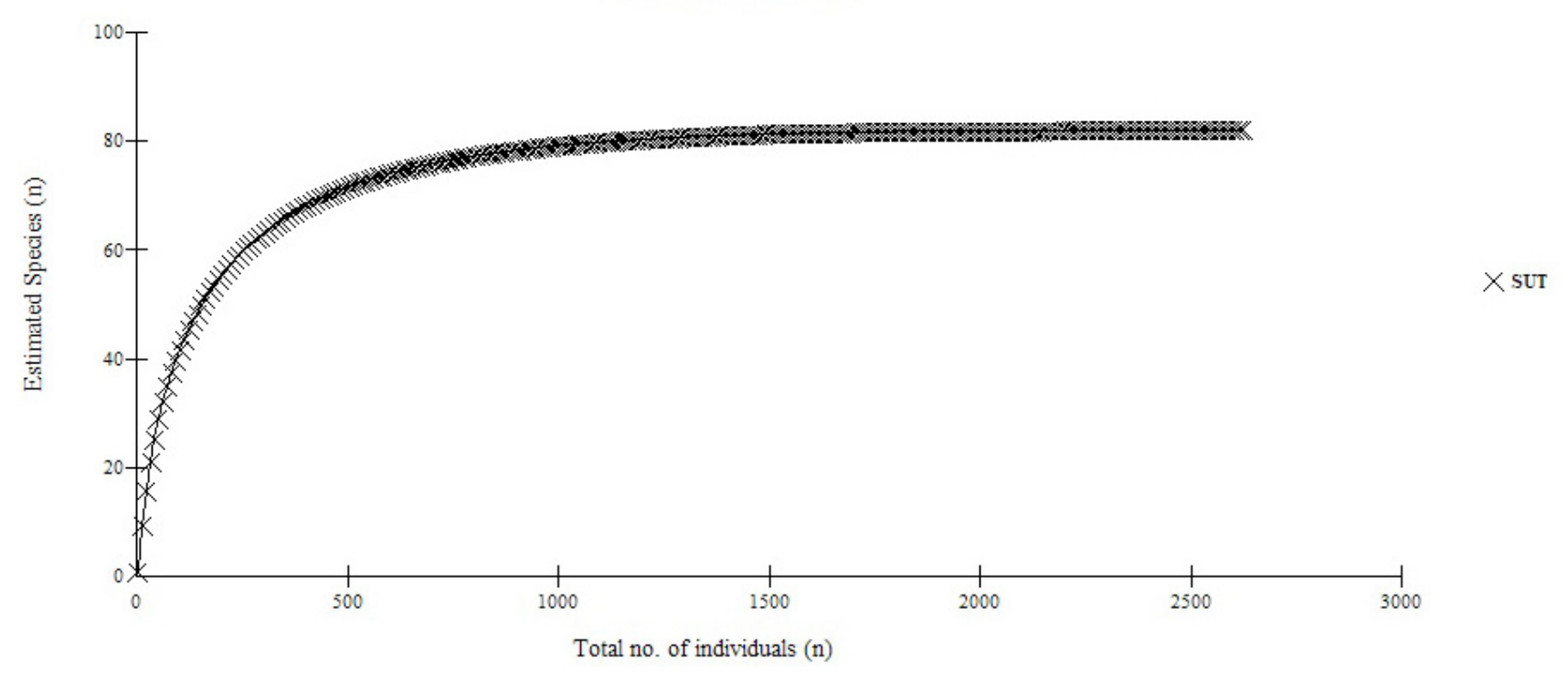

Fig. 1. Bird Species rarefaction curve at the site considered in this study. 
The categorization of rare species was based on the criteria used to define rarity (Gaston, 1994). In the present study, we defined that rare species were those that were sighted less than ten times throughout the study period. On comparing the overall rare species between the point count stations $29(23.01 \%)$ species were categorized as rare. The species rank abundance curve shows the relationship between the rare and common species in the study area (Fig. 2).

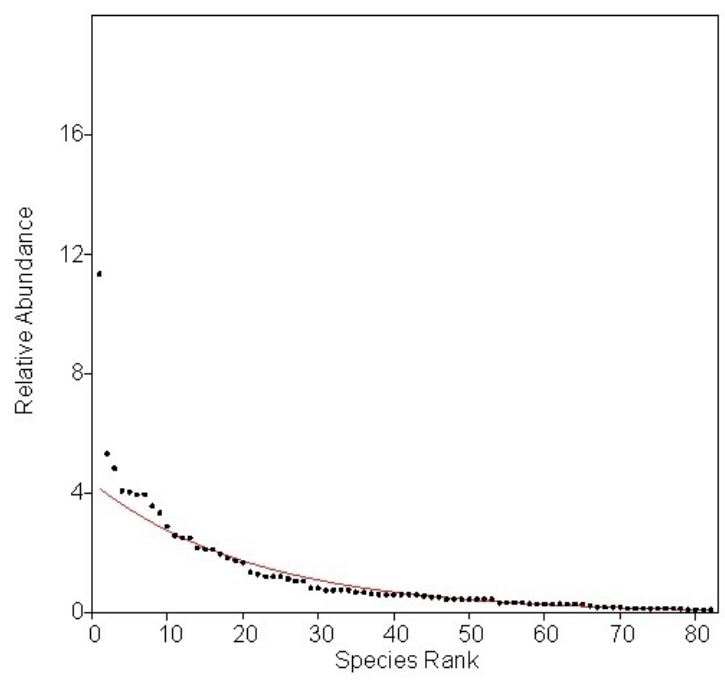

Fig. 2. Species rank abundance curve for rare and common species in the study area.

House sparrow Passer domesticus was the most abundant species in the study area, whereas the species with less than 4 individuals during the study period were common iora Aegithina tiphia, greater coucal Centropus sinensis, plain flowerpecker Dicaeum concolor and purplethroated sunbird Nectarinia sperata.

We observed six simple dietary guilds viz., insectivore (47), omnivore (20), granivore (9), carnivore (7), frugivore (6) and nectarivore (5). The maximum number of species belonged to insectivore group and minimum to nectarivore.

Dominant species are those which are highly successful ecologically and which determine to a considerable extent the conditions under which the associated species must live (Singh and Bhatt, 2004). Using the Berger-Parker dominance value (Table II), house sparrow was observed as the most dominating $(\mathrm{RA}=11.35)$ followed by oriental turtle dove $(\mathrm{RA}=5.33)$, peaceful dove $(R A=4.83)$, house swift $(\mathrm{RA}=4.06)$ and red collared dove $(\mathrm{RA}=4.03)$.

In the previous study of the SUT campus, 76 bird species were identified by Suwanwaree (2010); 65 were resident and 11 were winter visitor. Forty one species were non-passerines while the remaining 35 were passerines. No statistical analysis was carried out. The study undertaken by Suwanwaree (2010) was carried out twice a month during April to June 2010, while in the current study surveys were carried out on weekly basis from November 2016 to April 2017.

Many of the species reported in 2010 were not observed in the present study. However, the bird species richness 82 was higher in the present study compared to the previous study (76 species). Out of 124 species recorded in both the studies only 45 species are common in both studies (Supplementary Table II).

Table II.- Relative abundance of the dominant species in the study area.

\begin{tabular}{lc}
\hline Dominant species & $\begin{array}{c}\text { RA (relative } \\
\text { abundance) }\end{array}$ \\
\hline House sparrow, Passer domesticus & 11.352 \\
Oriental turtle dove, Streptopelia orientalis & 5.333 \\
Peaceful dove, Geopelia striata & 4.838 \\
House swift, Apus nipalensis & 4.076 \\
Red collored dove, Streptopelia tranquebarica & 4.038 \\
Asian house martin, Delichon dasypus & 3.962 \\
Common myna, Acridotheres tristis & 3.962 \\
Spotted dove, Streptopelia chinensis & 3.581 \\
Alexandrine parakeet, Psittacula eupatria & 3.352 \\
Rock pigeon, Columba livia & 2.895 \\
\hline
\end{tabular}

\section{DISCUSSION}

The findings of the study revealed a diverse avian population at the SUT campus. The total 94 species were observed during the study period, out of which 82 species were recorded in the point count stations and 12 species were observed between the point count stations. Data analysis was based only on the data recorded from the PCS, we observed high values of bird species ddiversity $(\mathrm{BSD}=3.808)$ and bird species richness $(\mathrm{BSR}=82)$ in the area might be because of the mixed vegetation profile in the region. This can be attributed to different factors such as availability of food, space and other resources that can affect the specialist species more pronouncedly than the generalist species. Difference in number of species can also be attributed to the migration trends of the species (Maan and Chaudhry, 2001). The difference in the pattern of relative abundance among the assemblages suggests that different factors or mechanisms could be involved in governing the inclusion of species in these assemblages (Tokeshi, 1999). Several other studies described that the distribution and abundance of bird species is determined by the configuration and composition of vegetation (vegetation complexity, tree species richness, diversity 
and environmental factors separately or in combination with one another) that comprises a major element of their habitat (Cody, 1985; Morrison, 1992; Block and Brennan, 1993). Many studies have demonstrated that the BSD and BSR are typically lower in urbanized habitats compared to the nearby natural habitats (Emlen, 1974; Walcott, 1974; Gavareski, 1976; Lancaster and Rees, 1979; Aldrich and Coffin, 1980; Beissinger and Osborne, 1982).

The presence of high BSD and BSR in this area might be due to the presence of more number of common species of available dietary guild. MacArthur (1972) and Weins (1989) stated that the type and quantity of resources as well as their distribution patterns are the major factors that determine the community structure of any particular regions.

The findings of the present study revealed that Insectivore guild was observed the most dominating guild. Some other studies support the dominance (Johnsingh and Joshua, 1994; Kropil, 1996; Sharma, 2001; Khan et al., 1993; Kwok and Corlett, 1999; Latta et al., 2003; O'Dae and Whittaker, 2007; Sultana et al., 2007) of bird communities by insectivores. However, a great percentage of bird species may utilize several food resources according to their availability (Humphery et al., 1970; Clark, 1986; Donazar et al.,1996; Smith-Ramirez and Armesto, 1998; Deferrari et al., 2001). In various other studies, it has been observed that insectivores respond more to habitat structure than to plant species composition because niche differentiating among insectivores is based largely on differences in their search and capture behavior which in turn relates to the parts of vegetation where the hunting bird forages (Cody, 1975; Terborgh, 1977, 1985; Desgranges, 1978; Fitzpatrick, 1980). In the present study the presence of nectarivore and frugivore birds was relatively low than other guilds. Weins (1989) and Naka (2004) also reported that the nectarivores are generally less represented in an avian community. The feeding guild structure of a community in a particular habitat is determined by available resources such as food, vegetation structure, suitable microhabitat and foraging substrates (Terborgh, 1977; Naka, 2004; Arriaga-Weiss et al., 2008; Sidra et al., 2013).

House sparrow was found to be the most dominant species in the study area. Similar to our results in some other studies also the House sparrow has been found dominating the bird community of urbanized habitats (Blair, 1996; Jokimaki et al., 2002; Naithani and Bhatt, 2012).

Besides, naturally vegetated areas, a large area adjacent to the university campus is under cultivation of important crops such as maize, rice, cassava and sugarcane. These cultivated areas are the important habitat for some bird species. Birds depend upon the food in the form of seeds, grains, weeds or insects. The agricultural fields provide all these types of foods besides favoring pests and other insect life, which attracts insectivorous birds like shrike, black drongo and thrush. The major influencing factor on the composition and distribution of bird species is the direct human intervention. Overall, residential neighborhoods, institutional grounds, and informal settlements can be considered as important bird areas in SUT campus.

The campus shares a great floristic diversity, providing many important stimuli for the bird life such as fruits, seeds, nectar, domestic residues, insects, small mammals, reptiles, and amphibians (Jokimaki and Jokimaki, 2012).

The conservation status of bird species was assessed using the latest information available from the IUCN Red List (2017) and the Thailand Wildlife Conservation and Protection Act (1992). Of all of the recorded species, only one Alexandrine parakeet was determined to be Near Threatened.

Our study provides a current and baseline information for urban decision makers and confirms the presence of good diversity of birds within the region. We conclude that the development and implementation of the campus and other urban areas and land-use plans should consider the biodiversity of areas that are closely associated with one another, such as villages in the close proximity of cities or other natural areas or protected areas or reserves. Diverse tree species should be planted near the campus. Creation of awareness among the students, teachers and public is very important for the conservation of birds within and around the University campus. Year round detailed systematic study would further elaborate present findings.

\section{ACKNOWLEDGEMENTS}

This research was supported by Suranaree University of Technology. We thank Dr. Phillips J. Grote for his guidance in identifying the plant species present on the campus and by the Office of the Higher Education Commission under NRU project of Thailand..

\section{Supplementary material}

There is supplementary material associated with this article. Access the material online at: http://dx.doi. org/10.17582/journal.pjz/2018.50.4.1257.1265

\section{Statement of conflict of interest}

Authors have declared no conflict of interest.

\section{REFERENCES}

Able, K.P. and Noon, B.R., 1976. Avian community 
structure along elevation gradients in the northeastern United States. Oecologia, 2: 275-294. https://doi.org/10.1007/BF00345296

Aldrich, J.W. and Coffin, R.W., 1980. Breeding bird population from forest suburban after 37 year. $\mathrm{Am}$. Birds, 34: 3-7.

Alig, R.J. and Healy, R.G., 1987. Urban and built-up land area changes in the United States: an empirical investigation of determinants. Land Econ., 63: 215 226. https://doi.org/10.2307/3146831

Arriaga-Weiss, S.L., Calme, S. and Kampicher, C., 2008. Bird communities in rainforests fragments, guild responses, habitat variables in Tabasco, Mexico. Biodiv. Conserv., 17: 173-190. https://doi. org/10.1007/s10531-007-9238-7

Beissinger, S.R. and Osborne, D.R., 1982. Effects of urbanization on avian community organization. Condor, 84: 75-83. https://doi.org/10.2307/1367825

Best, B.J. and Kessler, M., 1995. Biodiversity and conservation in Tumbesian Ecuador and Peru. BirdLife International, Cambridge, U.K.

Bibbly, C., Jones, C. and Marsden, S., 1998. Expedition field techniques: Bird surveys. Royal Geographical Society, London, UK.

Bird Life International, 2014. Psittacula eupatria. The IUCN red list of threatened species 2014: e.T22685434A62661113.

Blair, R.B., 1996. Land use and avian species diversity along an urban gradient. Ecol. Appl., 6: 506-519. https://doi.org/10.2307/2269387

Block, M.W. and Brennan, L.A., 1993. The habitat concept in ornithology. Curr. Ornithol., 11: 35-91. https://doi.org/10.1007/978-1-4757-9912-5_2

Bolger, D.T., 2002. Fragmentation effects on birds in southern California: contrast to the top-down paradigm? Stud. Avian Biol., 25: 141-157.

Bond, R.R., 1957. Ecological distribution of birds in the upland forest of Southwestern Wisconsin. Ecol. Monogr., 27: 351-384. https://doi. org/10.2307/1942269

Cellis-Murillo, A., Deppe, J.L. and Allen, M.F., 2009. Using soundscape recordings to estimate bird species abundance, richness and composition. $J$. Field Ornithol., 80: 64-78. https://doi.org/10.1111/ j.1557-9263.2009.00206.x

Cellis-Murillo, A., Deppe, J.L. and Ward, M.P., 2012. Effectiveness and utility of acoustic recordings for surveying tropical birds. J. Field Ornithol., 83: $166-179 . \quad h t t p s: / / d o i . o r g / 10.1111 / j .1557-$ 9263.2012.00366.x

Chaiyes, A., Duengkae, P., Wongwai, A. and Pratumthong, D., 2009. Influences of patch sizes on bird assemblages around western forest complex of Thailand. Thai J. Forest., 28: 1-12.

Clark, R., 1986. Aves de Tierra del Fuego y Cabo de Hornos. Guia de campo. LOLA ed., pp. 294.

Cody, M.L., 1974. Competition and structure of bird communities. Princeton University Press, Princeton, New Jersey.

Cody, M.L., 1975. Towards a theory of continental diversity: Bird distribution Mediterranean habitat gradients. In: Ecology and evolution of communities (eds. M.L. Cody and J.M. Diamond). Harvard University Press, Cambridge, MA, pp. 214-257.

Cody, M.L., 1985. An introduction to habitat selection in birds. In: Habitat selection in birds (ed. M.L. Cody). Academic Press, Inc., Orlando San Diego, New York, London, pp. 4-46.

Collar, N.J. and Andrew, P., 1988. Birds to watch: the ICBP world checklist of threatened birds. International Council for Bird Preservation and International Union for Conservation of Nature and Natural Resources, Cambridge, UK.

Crooks, K.R., Suarez, A.V. and Bolger, D.T., 2004. Avian assemblages along a gradient of urbanization in a highly fragmented landscape. Biol. Conserv., 115: 451-462. https://doi.org/10.1016/S00063207(03)00162-9

Deferrari, G., Camilion, C., Martinez Pastur, G. and Peri, P., 2001. Changes in Nothofagus pumilio forest biodiversity during the forest management cycle. Biodiv. Conserv., 10: 2093-2108. https://doi. org/10.1023/A:1013154824917

Desgranges, J.L., 1978. Avian community structure of six forest stands in Lamauria National Park. Canadian Wildlife Service, Quebec, OC, pp. 41.

Destefano, S. and Degraaf, R.M., 2003. Exploring the ecology of suburban wildlife. Front. Ecol. Environ., 1: 95-101. https://doi.org/10.1890/15409295(2003)001[0095:ETEOSW]2.0.CO;2

Donazar, J., Travaini, A., Rodriguez, A., Ceballos, O. and Hiraido, F., 1996. Nesting association of Rapotors and Buff-necked Ibis in the Argentinean Patagonia. Colon. Waterb., 19: 111-115. https://doi. org/10.2307/1521813

Duengkae, P., 2010. Avifaunal diversity on the Kasetsart university campus, Chalermphrakiat Sakon Nakhon Province. Kasetsart J. (Nat. Sci.), 44: 1107-1114.

Duengkae, P., Maneerat, S., Khobkhet, O., Pattanavibool, A., Kanithachat, P. and Karapan, S., 2001. Change in bird species assemblage in old settlement areas in Eastern Thung Yai Naresuan Wildlife Sanctuary. J. Wildl. Thailand, 9: 47-57.

Emlen, J.T., 1974. An urban bird community in Tucson 
Arizona. Derivation, structure, regulation. Condor, 76: 184-197. https://doi.org/10.2307/1366729

Fitzpatrick, J.W., 1980. Foraging behavior of Neotropical tyrant flycatchers. Condor, 82: 43-57. https://doi.org/10.2307/1366784

Gaston, K.J., 1994. Rarity, population and community biology, Series-13. Chapman and Hall, London.

Gavareski, C.A., 1976. Relation of park size and vegetation to urban bird populations in Seattle, Washington. Condor, 78: 375-382. https://doi. org/10.2307/1367699

Greenberg, R., 1996. Birds in the tropics. The coffee connection. Birding, 28: 472-480.

Gregory, R.D., Noble, D., Field, R., Marchant, J., Raven, M. and Gibbons, D.W., 2003. Using birds as indicators of biodiversity. Ornis Hung., 12: 1124.

Humphery, P.S., Bridge, D., Reynolds, P.W. and Peterson, R.T., 1970. Birds of Isla Grande (Tierra del Fuego).Smithsonian Institution, Washington D.C.

Iamsiri, A. and Gale, G.A., 2008. Breeding season habitat use by Hume's Pheasant Syrmaticus humiae in the Doi Chiang Dao Wildlife Sanctuary, Northern Thailand. Zool. Stud., 47: 138-145.

IUCN, 2017. The IUCN red list of threatened species, Version 2017. Available at: http://www.iucnredlist. org (accessed on 05 August 2017).

James, F.C., 1971. Ordinations of habitat relationships among breeding birds. Wilson Bull., 83: 215-236.

Johnsingh, A.J.T. and Joshua, J., 1994. Avifauna of three vegetation types of Mundanthurai Plateau, South India. J. Trop. Ecol., 10: 323-335. https://doi. org/10.1017/S0266467400007999

Jokimaki, J. and Kaisanlahti-Jokimaki, M.L., 2012. The role of residential habitat type on the temporal variation of wintering bird assemblages in northern Finland. Ornis Fenn., 88: 20-33.

Jokimaki, J., Clargeau, P. and Kaisanlahti-Jokimaki, M.L., 2002. Winter bird communities in urban habitats: a comparative study between central and northern Europe. J. Biogeogr., 29: 69-79. https:// doi.org/10.1046/j.1365-2699.2002.00649.x

Khobkhet, O., 2002. Birds in Bangkok. Department of Environmental Quality Promotion, Ministry of Natural Resources and Environment, Bangkok.

Khachonpisitsak, S. and Eiamprasert, S., 2015. Species diversity and abundance of birds in Si Chang Island Area, Ko Si Chang District, Chon Buri Province. Burapha Sci. J., 20: 56-72.

Khan, S. and Kanchanarat, K., 2012. A study of species diversity and species abundance of birds in
Phutthamonthon Park, Nakhon Pathom Province. Adv. Sci. J., 12: 121-126.

Khan, J.A., Khand, D.N. and Ahmed, A., 1993. Preliminary investigations of bird community structure at Aligarh, India. Trop. Ecol., 34: 217225.

Kristan, W.B., Lynam, A.J., Price, M.V. and Rotenberry, J.T., 2003. Alternative causes of edge-abundance relationships in birds and small mammals of California coastal sage scrub. Ecography, 26: 29-44. https://doi.org/10.1034/j.1600-0587.2003.03341.x

Kropil, R., 1996. Structure of the breeding bird assemblage of the fir-beech primeval forest in the West Carpathians (Badín nature reserve). Folia Zool., 45: 311-324.

Kwok, H.K. and Corlett, R.T., 1999. Seasonality of a forest bird community in Hong Kong, South China. Ibis, 141: 70-79. https://doi.org/10.1111/j.1474919X.1999.tb04264.x

Lancaster, R.K. and Rees. W.E., 1979. Bird communities and structure of urban habitats. Canadian J. Zool., 57: 2358-2368. https://doi.org/10.1139/z79-307

Latta, S.C., Rimmer, C.C. and Mcfarland, K.P., 2003. Winter bird communities in four habitats along an elevational gradient on Hispaniola. Condor, 105: 179-197. https://doi.org/10.1650/00105422(2003)105[0179:WBCIFH]2.0.CO;2

Lekagul, B. and Round, P.D., 2005. A guide to the birds of Thailand. Darnsutha Press, Bangkok.

Lim, H.C. and Sodhi, N.S., 2004. Responses of avian guilds to urbanisation in a tropical city. Landsc. Urban Plann., 66: 199-215. https://doi.org/10.1016/ S0169-2046(03)00111-7

Loreau, M., Naeem, S., Inchausti, P., Bengtsson, J., Grime, J.P., Hector, A., Hooper, D.U., Huston, M.A., Raffaelli, D., Schmid, B., Tilman, D. and Wardle, D.A., 2001. Biodiversity and ecosystem functioning: current knowledge and future challenges. Science, 294: 804-808. https://doi. org/10.1126/science. 1064088

Maan, M.A. and Chaudhry, A.A., 2001. Wildlife diversity in the Punjab (Pakistan). J. biol. Sci., 1: 417-420. https://doi.org/10.3923/jbs.2001.417.420

Macarthur, R.H. and Macarthur, J.W., 1961. On bird species diversity. J. Ecol., 42: 594-598. https://doi. org/10.2307/1932254

Macarthur, R.M., 1972. Geographical ecology. Patterns in the distribution of species. Harper and Row, New York.

Magurran, A.E., 1988. Ecological diversity and its measurement. Princeton University Press, Princeton, New Jersey. https://doi.org/10.1007/978- 
94-015-7358-0

Magurran, A.E., 2004. Measuring biological diversity. Blackwell Science, Ltd., Oxford, UK.

Maurer, B.A. and Whitmore, R.C., 1981. Foraging of five bird species in two forests with different vegetation structure. Wilson Bull., 93: 478-490.

Meckvichai, W., 2013. Birds in Chamchuri Park. Chulalongkorn University Printing House, Bangkok.

Morrison, M.L., 1992. Bird abundance of forests managed for timber and wildlife resources. Biol. Conserv., 60: 127-134. https://doi. org/10.1016/0006-3207(92)91163-M

Mortberg, U.M., 2001. Resident bird species in urban forest remnants; landscape and habitat perspectives. Landsc. Ecol., 16: 193-203. https:// doi.org/10.1023/A:1011190902041

Naka, L.N., 2004. Structure and organization of canopy bird assemblages in Central Amazonia. The Auk, 121: 88-102. https://doi.org/10.1642/00048038(2004)121[0088:SAOOCB]2.0.CO;2

Naithani, A. and Bhatt, D., 2012. Bird community structure in natural and urbanized habitats along an altitudinal gradient in Pauri district (Garhwal Himalayas) of Uttarakhand state, India. Biologia, 67: 1-9. https://doi.org/10.2478/s11756-012-0068-z

O’Dae, N. and Whittaker, R.J., 2007. How resilient are Andean montane forest bird communities to habitat degradation. Biodiv. Conserv., 16: 1131-1159. https://doi.org/10.1007/s10531-006-9095-9

Prathumthong, D. and Pattanavibool, A., 2006. Bird community structure along altitudinal gradients in a montane evergreen forest of Umphang Wildlife Sanctuary. J. Wildl. Thailand, 13: 138-148.

Ralph, C.J., Geupel, G.R., Pyle, P., Martin, T.E., Desante, D.F. and Milá, B., 1996. Manual de métodos de campo para el monitoreo de aves terrestres. Pacific Southwest Research Station, Forest Service, US Department of Agriculture.

Reynaud, P.A. and Thioulouse, J., 2000. Identification of birds as biological markers along neotropical urban-rural gradient (Cayenne, French Guiana), using coinertia analysis. J. Environ. Manage., 59: 121-140. https://doi.org/10.1006/jema.2000.0338

Round, P.D., 2008. The birds of the Bangkok area. White Lotus Co., Ltd., Bangkok.

Round, P.D. and Brockelman, W.Y., 1998. Bird community in disturbed lowland forest habitat of Southern Thailand. Nat. Hist. Bull. the Siam Soc., 46: 171-196.

Round, P. D. and Gale, G.A., 2008. Changes in the status of Lophura pheasants in Khao Yai National
Park, Thailand: A response to warming climate? Biotropica, 40: 225-230. https://doi.org/10.1111/ j.1744-7429.2007.00363.x

Savini, T. and Sukumal, N., 2009. Reproductive behaviour of two sympatric pheasant species at Khao Yai National Park, Thailand. Int. J. Gallif. Conserv., 1: 12-17.

Sharma, R.K., 2001. Avian diversity and vegetaitonal association in four distinct habitat types in Haridwar. Ph.D. dissertation, Gurukul Kangri University, Haridwar, Uttarakhand, India.

Sidra, S., Ali, Z. and Chaudhry, M.N., 2013. Avian diversity at new campus of Punjab University in relation to land use change. Pakistan J. Zool., 45: 1069-1082.

Singh, L.S. and Bhatt, D., 2004. Avian diversity and vegetational association in four distinct landscape elements in Bishnupur district and adjoining area of Manipur. Ph.D. dissertation, Gurukul Kangri University, Haridwar, Uttarakhand, India.

Siri, S., Duengkae, P. and Marod, D., 2013. Species diversity and abundance of birds in hill evergreen forest permanent plot at Huai Kok Ma, Chiang Mai Province. J. Wildl. Thailand, 20: 37-111.

Smith-Ramírez, C. and Armesto, J.J., 1998. Nectarivoria y polinizacion por aves en Embothrium cacenieum (Proteceae) en al bosque templado del sur de Chile. Rev. Chilena Hist. Nat., 71: 51-63.

Smith, W.J., 1977. The behaviour of communicating. Havard University Press, Cambridge, Massachusetts and London, pp. 545.

Sukmasuang, L., Duengkae, P., Bhumpakphan, N., Prathumtong, D. and Chokcharoen, R., 2009. Wildlife in Sra Prathum Palace. J. Wildl. Thailand, 16: $43-53$.

Sukmasuang, L., Duengkae, P., Prathumtong, D., Bhumpakphan, N. and Charakpukdee, L, 2007. Wildlife in Suan Chitralada, Suan Dusit Palace. J. Wildl. Thailand, 14: 1-29.

Sultana, A., Hussain, M.S. and Khan, J.A., 2007. Bird communities of the proposed Naina and Pindari wildlife sanctuaries in the Kumaon Himalayas, Uttarakhand, India. J. Bombay nat. Hist. Soc., 104: 19-29.

Sutherland, W.J., Pullin A.S., Dolman P.M. and Knight, T.M., 2004. The need for evidence-based conservation. Trends Ecol. Evol., 19: 305-308. https://doi.org/10.1016/j.tree.2004.03.018

Suwanrat, S., Ngoprasert, D., Sutherland, C., Suwanwaree, P and Savini, T., 2015. Estimating density of secretive terrestrial birds (Siamese Fireback) in pristine and degraded forest using 
camera traps and distance sampling. Glob. Ecol. Conserv., 3: 596-606. https://doi.org/10.1016/j. gecco.2015.01.010

Suwanwaree, P., 2010. The survey of butterfly, mammal, bird, reptile, and amphibian of Suranaree University of Technology campus: Research report. Suranaree University of Technology, Thailand.

Tarachai, P., 2012. Birds in Maejo University. Maejo Digital Printing House, Chiang Mai.

Teampanpong, J., Lauhachinda, V. and Wongthirawat, S., 2003. Comparison of bird communities between natural forest and disturbed forest along the natural gas pipeline right of way, Kanchanaburi Province. J. Wildl. Thailand, 11: 119-134.

Terborgh, J., 1977. Bird Species diversity on an Andean elevational gradient. Ecology, 58: 1007-1019. https://doi.org/10.2307/1936921

Terborgh, J., 1985. Habitat selection in Amazonian birds. In: Habitat selection in birds (ed. M.L. Cody). Academic Press, New York, pp. 311-338.

Thailand Wildlife Conservation and Protection Act,
1992. Available at: http://thailaws.com/law/t_laws/ tlaw0317.pdf (accessed on 13 February 2017).

Thammathaworn, S., Wara-Aswapati, O. and Grote, P.J., 1996. Survey of plants of the Suranaree University of Technology campus. Flora of Thailand meeting, Phuket, Thailand, pp. 33.

Tokeshi, M., 1999. Species coexistence: Ecological and evolutionary perspectives. Blackwell Science Ltd., United Kingdom.

Walcott, C.F., 1974. Changes in bird life in Cambridge, Massachusetts from 1860 to 1964 . The Auk, 91: 151-160. https://doi.org/10.2307/4084670

Weins, J.A., 1989. The ecology of bird communities. Foundations and Patterns. Vol. 1, Cambridge University Press, Cambridge, pp. 539. https://doi. org/10.1017/CBO9780511608568

Wongthirawat, S., 2009. Using birds as ecological indicators. National Park, Wildlife and Plant Conservation Department, Ministry of Natural Resources and Environment, Bangkok. 